\title{
Effect of garlic supplementation on zootechnical performance and hepato-renal functions in nitrate-treated rabbits
}

\author{
G. Rashid ${ }^{1}$, A. Nasir ${ }^{2}$, M. Avais ${ }^{3}$, M. Adil ${ }^{4}$, A. Sikandarr" ${ }^{5 \#}$ M. Kashif ${ }^{2}$, I. Irshad ${ }^{6}$ \& H. Ullah $^{7}$ \\ ${ }^{1}$ Department of Livestock \& Dairy Development, Baluchistan-Pakistan \\ ${ }^{2}$ Department of Clinical Sciences, University of Veterinary \& Animal Sciences, Lahore-Jhang campus, Pakistan \\ ${ }^{3}$ Department of Veterinary Medicine, University of Veterinary \& Animal Sciences, Lahore-Pakistan \\ ${ }^{4}$ Pharmacology \& Toxicology Section, University of Veterinary \& Animal Sciences, Lahore-Jhang campus, Pakistan \\ ${ }^{5}$ Anatomy \& Histology Section, University of Veterinary \& Animal Sciences, Lahore-Jhang campus, Pakistan \\ ${ }^{6}$ Institute of Continuing Education \& Extension, University of Veterinary \& Animal Sciences, Lahore-Ravi campus, \\ Pattoki, Pakistan \\ ${ }^{7}$ Faculty of Veterinary \& Animal Sciences, Gomal University, Dera Ismail Khan, Pakistan
}

(Received 24 January 2021; Accepted 8 May 2021; Published 16 August 2021)

\author{
Copyright resides with the authors in terms of the Creative Commons Attribution 4.0 South African Licence. \\ See: http://creativecommons.org/licenses/by/4.0/za \\ Condition of use: The user may copy, distribute, transmit and adapt the work, but must recognise the authors and the South African \\ Journal of Animal Science
}

\begin{abstract}
The effect of garlic supplementation on zootechnical performance and hepato-renal functions of rabbits exposed to experimental nitrate poisoning was evaluated. Adult male 6-8 week-old albino rabbits $(n=$ 24) were randomly divided into four groups $(A-D)$ and subjected to nitrate intoxication through the oral administration of sodium nitrate solution at $2 \mathrm{ml} / \mathrm{kg}$ bodyweight per day for 40 days. Group A was a control that received no treatment except sodium nitrate. Rabbits in groups $B$ and $C$ were treated with $1 \%$ methylene blue solution ( $2 \mathrm{mg} / \mathrm{kg}$ bodyweight per day) and aqueous garlic extract (500 mg/kg bodyweight per day) through intraperitoneal and oral routes, respectively. Rabbits in group D were treated with both $1 \%$ methylene blue solution ( $2 \mathrm{mg} / \mathrm{kg}$ bodyweight per day, intraperitoneally) and aqueous garlic extract (500 $\mathrm{mg} / \mathrm{kg}$ bodyweight per day, orally). On completion of the treatment period, the groups were compared in growth performance, biochemical profile and histopathological changes of hepato-renal tissues. Although the total feed consumption of the groups remained comparable, Group $\mathrm{C}$ showed relatively better weight gain and feed conversion ratio (FCR). Likewise, garlic extract significantly increased the serum bilirubin concentration and reduced the level of other biochemical attributes in comparison with control animals. The hepatic and renal tissues of Groups C and D remained normal, whereas those of the control group exhibited distinct histopathological alterations. It was concluded that garlic supplementation ameliorated the deleterious effects of nitrate intoxication on production performance and hepato-renal functions of rabbits.
\end{abstract}

Keywords: garlic, kidney, liver, nitrate, rabbits, zootechnical performance

\#Corresponding author: arbab.sikandar@uvas.edu.pk

\section{Introduction}

Nitrate is a known contaminant of drinking water, aquatic ecosystems, and animal fodder. Sewage water, industrial processes and indiscriminate application of fertilizers form the major sources of nitrate. The gradually increasing nitrate level of ground water has been implicated in triggering detrimental effects in humans and animals (Ward et al., 2010; Band et al., 2020). The consumption of water or feed contaminated with nitrate by farm animals frequently leads to outbreaks of nitrate poisoning throughout the world (Ozmen et al., 2003). The utilization of nitrate follows the synthesis of nitric oxide and its conversion into the reactive molecule peroxynitrite, which plays a critical role in the pathogenesis of many disease conditions (Luiking et al., 2010). Following the reduction of nitrate, nitrite binds readily with haemoglobin and forms methemoglobin, which is characterized by deficiency in oxygen-carrying capacity. Fatal methemoglobinemia and hepato-renal toxicity have been attributed to high intakes of nitrate (Baek et al., 2015). Although several animal species suffer from nitrate poisoning, cattle exhibit relatively high susceptibility owing to the presence of ruminal micro-organisms, which rapidly catalyse the conversion of nitrate into highly toxic nitrite. In addition, the oxidative stress mediated by reactive metabolites such as peroxynitrite and peroxides has been 
postulated as the basis of nitrate-induced toxicity (Saracila et al., 2020). Methylene blue has been long regarded as a front-line antidote to nitrate poisoning (Van Dijk et al., 1983). However, its clinical application is confounded by the lack of veterinary-specific formulations and potential carcinogenicity (Haskell et al., 2005). The therapeutic potential of garlic (Allium sativum) has been demonstrated in the context of several pathological conditions (El-Saber Batiha et al., 2020; Nakamoto et al., 2020). Garlic has been reported to mitigate the neurotoxicity (Hassan et al., 2009), uropathogen invasion (Lionel et al., 2020), nephrotoxicity (Pedraza-Chaverri et al., 2008), and cardiac damage (Islam et al., 2020) associated with oxidative stress in animal models. The present study was designed to investigate the protective effect of garlic supplementation in rabbits that had been subject to nitrate poisoning.

\section{Materials and methods}

Male albino rabbits $(n=24)$, of equivalent age $(6-8$ weeks $)$ and bodyweight $(1200-1400$ grams $)$ were randomly divided into four groups (A to D), after an acclimatization period of two weeks. The rabbits were kept at a temperature of $25^{\circ} \mathrm{C}$, and 12-hour daylight was provided. The basal diet was prepared for rabbits according to Singh (2005) with minor modifications for the current local environment (Table 1). Each rabbit received $90 \mathrm{~g} / \mathrm{kg} /$ day of feed. Leftover feed was collected frequently, weighed and discarded. Fresh and clean drinking water was offered ad libitum. All protocols of animal handling were approved by the institutional ethics committee (DR/97, 07/03/2016).

Table 1 Dietary ingredients and calculated nutrient composition of basal diet for rabbits (\%, as-fed basis)

\begin{tabular}{lclc}
\hline Ingredients & $\%$ & \multicolumn{2}{c}{ Calculated nutrient content } \\
\hline Wheat bran & 53 & Crude protein, \% & 16.4 \\
Maize & 30 & Crude fibre, \% & 8.0 \\
Cottonseed meal & 10 & Ether extract, \% & 5.0 \\
Fish meal & 5 & Crude ash, \% & 5.50 \\
Mineral mixture & 1.5 & Lysine, \% & 0.72 \\
Salt & 0.5 & Methionine, \% & 0.30 \\
& & Calcium, \% & 0.5 \\
& & Phosphorus, \% & 0.91
\end{tabular}

Vitamin $B_{2}$ and vitamin $D_{3}$ were added at $10 \mathrm{mg} / 100 \mathrm{~kg}$ of feed

The sodium nitrate test solution $(0.2 \mathrm{~g} / \mathrm{mL})$ was freshly prepared by dissolving 20 grams of sodium nitrate in $100 \mathrm{ml}$ clean drinking water. The potentially toxic dose of sodium nitrate ( $400 \mathrm{mg} / \mathrm{kg}$ bodyweight) was administered to rabbits by giving the prepared sodium nitrate solution at $2 \mathrm{ml} / \mathrm{kg}$ bodyweight per day via gavage needle (Sharma et al., 2013). Aqueous garlic extract $(500 \mathrm{mg} / \mathrm{mL})$ was prepared by homogenizing 30 grams of peeled and chopped garlic with $60 \mathrm{ml}$ of distilled water (Rashid et al., 2019).

Treatments were administered for 40 days. All groups received sodium nitrate solution at $2 \mathrm{ml} / \mathrm{kg}$ bodyweight per day via gavage needle. Additionally, $1 \%$ methylene blue solution ( $2 \mathrm{mg} / \mathrm{kg}$ bodyweight) and aqueous garlic extract $(500 \mathrm{mg} / \mathrm{kg}$ bodyweight) were administered intraperitoneally and orally to rabbits of Groups B and C, respectively. The rabbits of Group D were co-treated with $1 \%$ methylene blue solution (2 $\mathrm{mg} / \mathrm{kg}$ bodyweight) and aqueous garlic extract (500 mg/kg bodyweight) via intraperitoneal and oral routes, respectively.

The total feed consumption (FC) and bodyweight gain (BWG) were recorded for all rabbits at the end of the trial (day 40). Feed conversion was calculated for each rabbit as the ratio of total WG to total FC.

Blood samples were collected from all rabbits on day 40 and sera were extracted by centrifugation at $5000 \mathrm{rpm}$ for 5 minutes. The serum samples were stored at $4{ }^{\circ} \mathrm{C}$ and analysed (Lulekal et al., 2019). Biochemical parameters such as alanine amino transferase (ALT), aspartate transaminase (AST), alkaline phosphatase (ALP), bilirubin, urea, uric acid and creatinine were measured according to company instructions using commercial kits (Human Gesellschaft fur Biochemical und Diagnostica GmbH, Wiesbaden, Germany).

At the end of trial, three rabbits were randomly selected from each group, euthanized by cervical 
dislocation, and subjected to post-mortem examination. The representative samples of hepatic and renal tissues were processed for histopathological examination (Sikandar et al., 2012) using haematoxylin and eosin (H\&E) staining. The stained slides were examined microscopically at 10x magnification for histopathological changes.

Data were analysed by one-way analysis of variance (ANOVA) using the Statistical Package for Social Sciences (SPSS Inc., Chicago, IL, USA), version 21.0. The means values of parameters were compared among groups by the least significant difference test at a probability $P \leq 0.05$.

\section{Results and Discussion}

Although the total FC and FCR of various groups were not different, significant differences were evident in net WG (Table 2). The highest WG was observed for rabbits in group $D$. Rabbits in the group $A$ exhibited the lowest values of total FC, net WG and FCR. The rabbits in groups $B$ and $C$ were intermediate between groups $A$ and $D$ with the rabbits treated with the $1 \%$ methylene blue solution growing faster than those treated with the garlic extract.

Table 2 Treatment effects on weight gain and feed consumption of rabbits subjected to nitrate poisoning for 40 days, six rabbits per group

\begin{tabular}{lcccc}
\hline \multicolumn{1}{c}{ Treatments $^{1}$} & Group & Feed consumed, g & Weight gain, g & FCR \\
\hline Control & A & $3313 \pm 80.170^{\mathrm{a}}$ & $137.17 \pm 0.17^{\mathrm{a}}$ & $0.041 \pm 0.009^{\mathrm{a}}$ \\
$1 \%$ methylene blue solution & B & $3465 \pm 97.851^{\mathrm{a}}$ & $166.50 \pm 1.18^{\mathrm{b}}$ & $0.047 \pm 0.001^{\mathrm{a}}$ \\
$\begin{array}{l}\text { Aqueous garlic extract } \\
1 \% \text { methylene blue solution and aqueous } \\
\text { garlic extract }\end{array}$ & C & $3442 \pm 106.038^{\mathrm{a}}$ & $154.17 \pm 0.48^{\mathrm{c}}$ & $0.044 \pm 0.002^{\mathrm{a}}$ \\
& D & $3485 \pm 144.058^{\mathrm{a}}$ & $187.33 \pm 3.50^{\mathrm{d}}$ & $0.053 \pm 0.002^{\mathrm{a}}$
\end{tabular}

\footnotetext{
${ }^{1}$ Methylene blue solution provided intra-peritoneally at $2 \mathrm{mg} / \mathrm{kg}$ bodyweight, aqueous garlic extract provided orally at 500 $\mathrm{mg} / \mathrm{kg}$ bodyweight; FCR: weight gain divided by feed consumed

a,b,c.d Means in the same column bearing a common superscript were not different at $P<0.05$
}

The biomarkers of hepatic function were substantially different among the control and treatment groups (Table 3). The control group displayed significantly higher values of ALT, AST, and ALP, but a lower level of bilirubin in comparison with the treated groups. On the other hand, group D had significantly higher values of bilirubin than the other groups, with the groups $B$ and $C$ also having higher levels of bilirubin than the control.

Table 3 Treatment effects on hepatic biomarkers of rabbits subjected to nitrate poisoning for 40 days, six rabbits per group

\begin{tabular}{lccccc}
\hline Treatments $^{1}$ & Group & ALT, U/L & AST, U/L & ALP, U/L & Bilirubin, mg/dl \\
\hline Control & A & $81.54 \pm 3.64^{\mathrm{a}}$ & $95.72 \pm 3.91^{\mathrm{a}}$ & $25.62 \pm 4.31^{\mathrm{a}}$ & $0.18 \pm 0.02^{\mathrm{a}}$ \\
$1 \%$ methylene blue solution & B & $50.63 \pm 2.60^{\mathrm{b}}$ & $51.54 \pm 3.67^{\mathrm{b}}$ & $16.57 \pm 2.22^{\mathrm{b}}$ & $0.42 \pm 0.04^{\mathrm{b}}$ \\
Aqueous garlic extract & $\mathrm{C}$ & $49.75 \pm 2.46^{\mathrm{b}}$ & $52.75 \pm 3.46^{\mathrm{b}}$ & $15.62 \pm 2.45^{\mathrm{b}}$ & $0.51 \pm 0.05^{\mathrm{b}}$ \\
$1 \%$ methylene blue solution & $\mathrm{D}$ & $45.37 \pm 1.68^{\mathrm{b}}$ & $46.63 \pm 2.68^{\mathrm{b}}$ & $11.83 \pm 1.52^{\mathrm{b}}$ & $0.69 \pm 0.06^{\mathrm{c}}$ \\
and aqueous garlic extract & & & & &
\end{tabular}

\footnotetext{
${ }^{1}$ Methylene blue solution provided intraperitoneally at $2 \mathrm{mg} / \mathrm{kg}$ bodyweight, aqueous garlic extract provided orally at 500 $\mathrm{mg} / \mathrm{kg}$ bodyweight;

ALT: alanine amino transferase, AST: aspartate transaminase, ALP: alkaline phosphatase

${ }_{\mathrm{a}, \mathrm{b}, \mathrm{c}}$ means in the same column bearing a common superscript were not different at $P<0.05$
}

The levels of uric acid, urea and creatinine of the rabbits in the groups are shown in Table 4. Overall, the comparison of hepato-renal biomarkers revealed significant differences between the control and the treated groups. The highest and lowest values of serum uric acid, urea and creatinine were documented for 
groups $A$ and $D$, respectively.

Table 4 Treatment effects on renal biomarkers of rabbits subjected to nitrate poisoning for 40 days, six rabbits per group

\begin{tabular}{lcccc}
\hline Treatments $^{1}$ & Group & Uric acid, $\mathrm{mg} / \mathrm{dl}$ & Urea, mg/dl & Creatinine, mg/dl \\
\hline Control & A & $4.04 \pm 0.27^{\mathrm{a}}$ & $40.02 \pm 3.60^{\mathrm{a}}$ & $2.68 \pm 0.25^{\mathrm{a}}$ \\
$1 \%$ methylene blue solution & B & $2.54 \pm 0.24^{\mathrm{b}}$ & $31.24 \pm 3.75^{\mathrm{ab}}$ & $1.45 \pm 0.19^{\mathrm{b}}$ \\
Aqueous garlic extract & $\mathrm{C}$ & $2.73 \pm 0.26^{\mathrm{b}}$ & $32.03 \pm 2.48^{\mathrm{ab}}$ & $1.38 \pm 0.24^{\mathrm{b}}$ \\
$1 \%$ methylene blue solution and & $\mathrm{D}$ & $1.98 \pm 0.35^{\mathrm{b}}$ & $27.45 \pm 2.88^{\mathrm{b}}$ & $0.98 \pm 0.14^{\mathrm{b}}$ \\
aqueous garlic extract & & &
\end{tabular}

\footnotetext{
${ }^{1}$ Methylene blue solution provided intraperitoneally at $2 \mathrm{mg} / \mathrm{kg}$ bodyweight, aqueous garlic extract provided orally at 500 $\mathrm{mg} / \mathrm{kg}$ bodyweight

${ }_{a, b, c}$ Means in the same column with a common superscript were not different at $P<0.05$
}

The hepatic sections of the control animals indicated severe vacuolar degeneration, coagulative necrosis, swollen hepatocytes and narrowing of the sinusoidal spaces (Figure 1a). The liver tissues of the rabbits in group $B$ had hepatocytes in cords with frequent nucleolar degeneration (Figure 1b). Cytomegalic hepatocytes with pyknotic nuclei, massive karyorrhexis and karyolysis were found in the hepatic sections (Figure 1c) of the rabbits in group $C$ The hepatocytes of rabbits in group D were characterized by healthy parenchyma and nuclear architecture (Figure 1d).

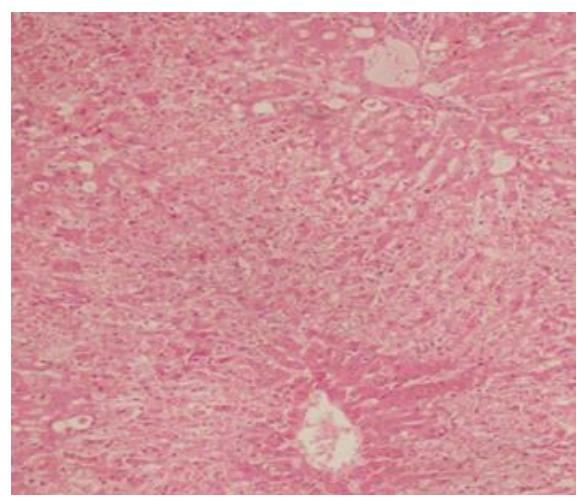

Figure 1a

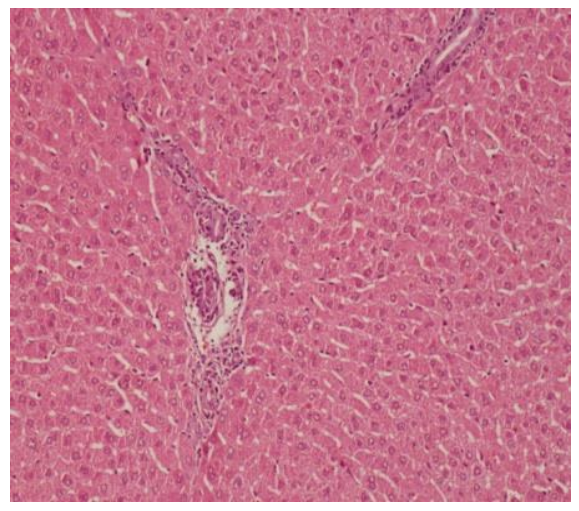

Figure 1c

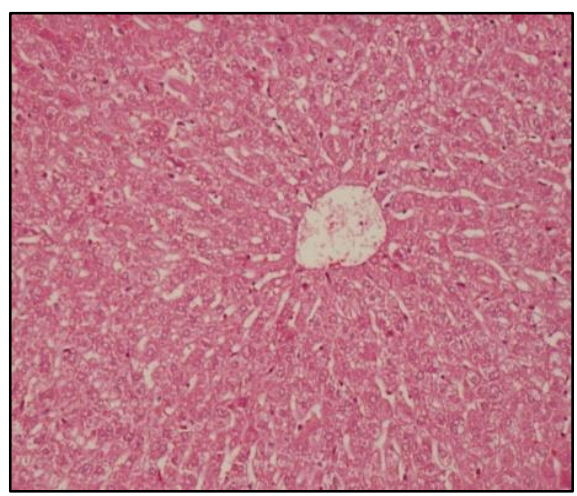

Figure 1b

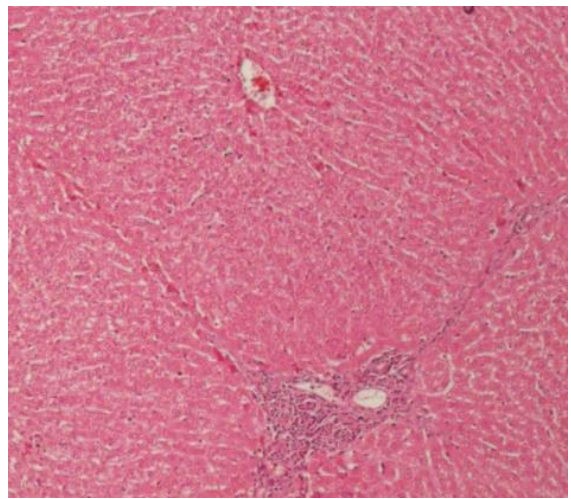

Figure 1d

Figure 1 Microscopic images (100x) of liver sections stained with haematoxylin and eosin from control rabbits (Figure 1a), rabbits treated with methylene blue (Group B) (Figure 1b), rabbits that received aqueous garlic extract (Group C) (Figure 1c), and rabbits that were co-treated with methylene blue and aqueous garlic extract (Group D) (Figure 1d). 
Marked infiltration of inflammatory cells was observed in the renal parenchyma of the control rabbits along with resultant multifocal necrosis. Moreover, pressure atrophy of renal tubules and congestion of renal tubular capillaries were discernible (Figure 2a). The renal parenchyma of group B indicated sporadic haemorrhages, coagulative necrosis and fragmented nuclei. In addition, swollen epithelial cells with typical moth-eaten appearance lined the renal tubules (Figure 2b). Degenerated renal tubules with desquamated epithelial lining, congested renal corpuscles and presence of fibrinous mass (protein casts) in the tubular lumen (Figure 2c) were observed in the kidney tissues of rabbits in group C. On the other hand, the renal tubules of rabbits in group D were lined with healthy epithelial cells and were devoid of major histopathological lesions (Figure 2d).

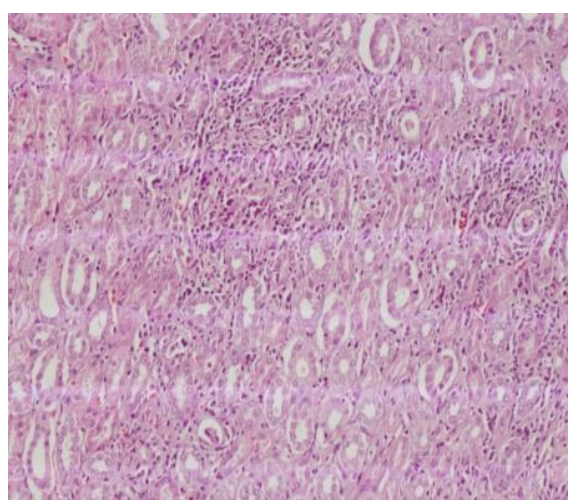

Figure $2 \mathrm{a}$

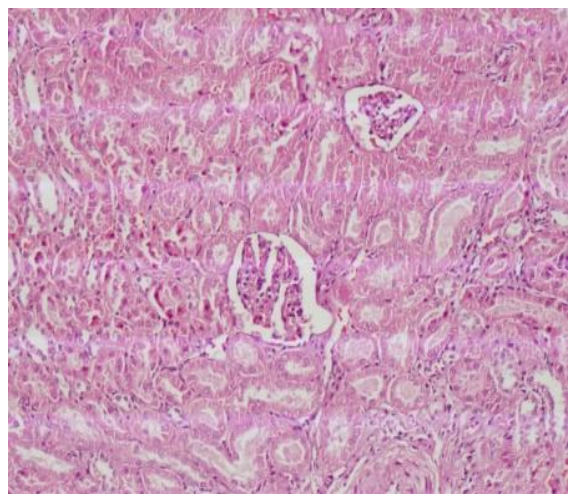

Figure 2c

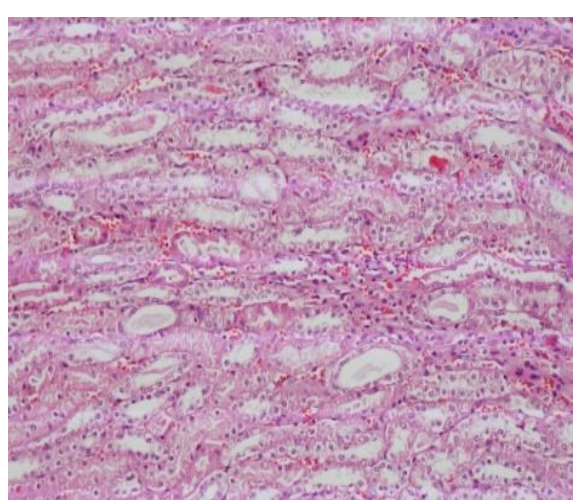

Figure 2b

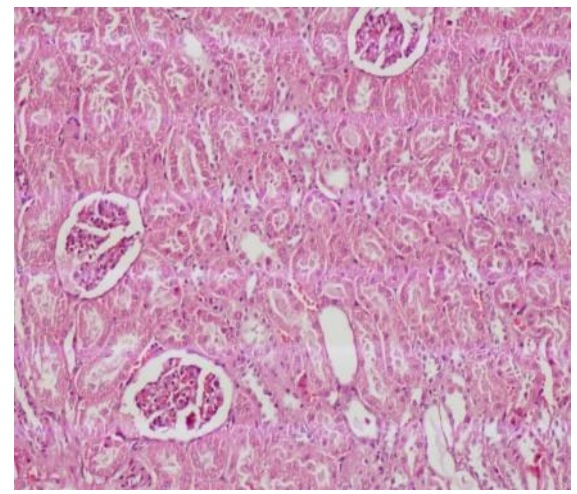

Figure 2d

Figure 2 Microscopic images (100x) of kidney sections stained with haematoxylin and eosin from control rabbits (Group A) (Figure 2a), rabbits treated with methylene blue (Group B) (Figure 2b), rabbits that received aqueous garlic extract (Group C) (Figure 2c), and rabbits that were co-treated with methylene blue and aqueous garlic extract (Group D) (Figure 2d)

Nitrate poisoning in animals is manifested by varied symptoms, depending upon the level of exposure involving multiple body systems and is a serious challenge. The current study revealed no difference between the control and treated groups in terms of total FC. But although nitrate did not affect the FC, it decreased the FCR of exposed rabbits significantly. Hence, the current investigation showed that nitrate exerted an inherent untoward effect on rabbit performance by significantly restricting WG and thereby reducing the FCR. Similar reduction in the growth performance and FCR of rabbits was reported from the consumption of drinking water containing nitrate (Shehata, 2010). This diminished feed digestibility could be ascribed to nitrate-mediated impairment of the absorptive and secretory functions of intestinal mucosa (Qin et al., 2020).

The elevated serum levels of AST, ALT, and ALP in nitrate-affected rabbits strengthened the findings of earlier studies (Ogur et al., 2005; Salama et al., 2013; Bouaziz-Ketata et al., 2014; Maklad et al., 2020). The toxic effects of nitrates have been known to induce oxidative stress, leading to liver insult and a rise in the levels of liver enzymes. Likewise, the synthesis of nitroso-compounds in the acidic environment of 
stomach and consequent hepatotoxic effect were hypothesized to increase the serum concentrations of liver enzymes (Hassan et al., 2009; Enovwo, 2010). Besides, the outflow of hepatic enzymes results from hypoxic injury to centrilobular hepatocytes, which is triggered by anaemia and methemoglobinemia (Ibrahim et al., 2009). The leakage of enzymes from hepatic cytosol into systemic blood, and inadequate enzyme synthesis, together with increased permeability of hepatic membrane, have also been postulated (Aboulgasem et al., 2015). The observed decline in serum bilirubin concentration of nitrate-treated rabbits could be attributed to increased production of free amino acids and reduced protein turnover owing to stimulation of adrenal and thyroid glands (Hassan et al. 2009; Enovwo, 2010; Aboulgasem et al., 2015; Alagawany et al., 2016). The negative effect of nitrate supplementation on total protein concentration has also been reported owing to the toxic effects of nitrates in animals and human (Alrawi, 2016). Nitrate-induced oxidative injury to hepatic cell membranes leads to diminished serum levels of bilirubin (Salama et al., 2013). Significantly elevated serum levels of urea, uric acid and creatinine depicted the renal malfunction in rabbits following the oral intake of sodium nitrate at $400 \mathrm{mg} / \mathrm{kg}$ BW for 40 days. The increase in urea level recorded among rabbits of the experimental groups in the current study is in line with the reported rise in its level during a study on adult female New Zealand rabbits in Iraq (Alrawi, 2016). This may be linked to the deteriorating effect of nitrate on liver metabolism and kidney function (Sharma et al., 2014). Similarly, the observed increase in the level of creatinine, in line with the findings of Attia et al. (2018), might indicate the untoward effects of nitrate on renal function. These findings conform with those of former studies (Hassan et al., 2009; Aboulgasem et al., 2015). Altered renal blood flow, tubular re-absorption and glomerular absorption were proposed to increase the serum concentrations of renal function bio-indicators (Enovwo, 2010).

In addition, marked histopathological lesions reflected the hepatotoxic and nephrotoxic effects associated with nitrate consumption in rabbits. Similar histopathological changes were documented in rabbits affected by nitrate (Sharma et al., 2013) and rats (Bouaziz et al., 2015; Ansari et al., 2017). Histological alterations in the normal parenchyma and epithelial lining are known to weaken the gastrointestinal physiology (Sikandar et al., 2020). Chronic utilization of sodium nitrite led to renal carcinogenicity and nephrotoxicity in rats (Al-Gayyar et al., 2016). The number of white blood cells was severely reduced in rabbits fed nitrate owing to its potential oxidative effect (Ansari et al., 2017) and T cells have an important immune response role as anti-cancerous defence (Waldman et al., 2020). The hepato-nephrotoxic effects of sodium nitrate in rabbits were normalized by garlic extract administered alone (group C) or combined with methylene blue (group D). These results validated the potential use of garlic extract to mitigate nitrateinduced toxicity.

Garlic contains antioxidant compounds, including allicin, alliin, allyl disulfide and allyl cysteine (Elkelawy et al., 2017). The chemical reaction between nitrate and food amines that occurs in the stomach yields free radicals and nitrosamines, which induce the lipid peroxidation of multiple organs, particularly the liver and kidneys (Choi et al., 2002). In addition to the blockage of xanthine oxidase enzyme, garlic scavenges hydroxyl radicals, singlet oxygen, peroxy radicals and peroxynitrite responsible for oxidative cell injury (Saravanan \& Prakash, 2004). Hepatic anti-oxidant enzymes have been increased considerably by feeding garlic and turmeric to growing rabbits in Egypt and thus protecting liver functioning by preventing oxidative injury (Alagawany et al., 2016). In contrast with other species of Allium, garlic contains several sulfur-containing compounds in much higher concentrations (El-Saber Batiha et al., 2020). Dried garlic powder contains about $1 \%$ alliin (S-Allyl-L-cysteine sulfoxide) and injury to garlic bulb results in the production of its active ingredient allicin (Diallyl thiosulfinate). Accordingly the protective effect of garlic against nitrateinduced toxicity could be attributed to the antioxidant effect of sulfur-containing compounds (Aslani et al., 2006).

\section{Conclusion}

Garlic extract counteracted the deleterious effects of sodium nitrate on zootechnical performance and hepato-renal functions of rabbits with similar efficacy to methylene blue. Therefore, garlic extract could be used effectively alone or in combination with methylene blue to combat nitrate intoxication. Further research is recommended on the antioxidant profile of exposed animals and dose-response relationship of garlic extract and nitrate poisoning.

\section{Authors Contributions}

GR and MA contributed to planning and establishment of the experimental shed, AS and HU arranged the research materials, MA, MK and II conducted the experimental research work, and AS and MA wrote the manuscript.

\section{Conflict of Interest Declaration}

The authors declare that there is no conflict of interest. 


\section{References}

Aboulgasem, G.J., Azab, A.E.S. \& Almaky, M.M., 2015. Sodium nitrite induced biochemical alterations in the blood serum and its amelioration by aqueous extract of Libyan propolis in guinea pigs. Int. J. Sci. Res. 4(8), 1040-1048.

Alagawany, M., Ashour, E. A. \& Reda, F. M., 2016. Effect of dietary supplementation of garlic (Allium sativum) and turmeric (Curcuma longa) on growth performance, carcass traits, blood profile and oxidative status in growing rabbits, Annals of Animal Science 16(2), 489-505. https://doi.org/10.1515/aoas-2015-0079

Al-Gayyar, M.M., Hassan, H.M., Alyoussef, A., Abbas, A., Darweish, M.M. \& El-Hawwary, A.A., 2016. Nigella sativa oil attenuates chronic nephrotoxicity induced by oral sodium nitrite: Effects on tissue fibrosis and apoptosis. Redox Report 21(2), 50-60. doi.org/10.1179/1351000215Y.0000000035

Alrawi, S.T.J., 2016. The effect of nitrate on some biochemical parameters of rabbits and ameliorate its effect by using vitamin $\mathrm{E}$ and rosemary (Rosmarinus officinalis). 11 (4), 145-150.

Ansari, F.A., Ali, S.N., Khan, A.A. \& Mahmood, R., 2017. Acute oral dose of sodium nitrite causes redox imbalance and DNA damage in rat kidney. J. Cel. Biochem. 119(4), 3744-3754. doi.org/10.1002/jcb.26611

Aslani, M.R.M., Mohri, M. \& Chekani, M., 2006. Effects of garlic (allium sativum) and its chief compound, allicin, on acute lethality of cyanide in rats. Comp. Clin. Path. 15(4), 211-213. doi.org/10.1007/s00580-006-0633-3

Baek, J.H., Zhang, X.Y., Williams, M.C., Hicks, W., Buehler, P.W. \& D'Agnillo, F., 2015. Sodium nitrite potentiates renal oxidative stress and injury in hemoglobin exposed guinea pigs. Toxicology 333, 89-99. doi: 10.1016/j.tox.2015.04.007

Band, S.S., Janizadeh, S., Pal, S.C., Chowdhuri, I., Siabi, Z., Norouzi, A., Melesse, A.M., Shokri, M. \& Mosavi, A., 2020. Comparative analysis of artificial intelligence models for accurate estimation of groundwater nitrate concentration. Sensors 20(20),5763. doi.org/10.3390/s20205763

Bouaziz, H., Rafrafi, M., Salah, G.B., Marrekchi, R., Kammoun, H., Jamoussi, K., Boudawara, T. \& Zeghal, N., 2015. Nitrate provoked kidney toxicity and DNA impairment in adult rats: Alleviation by Hyparrhenia hirta. Pak. Vet. J. 35(4), 397-402.

Bouaziz-Ketata, H., Salah, G.B., Salah, H.B., Marrekchi, R., Jamoussi, K., Boudawara, T., Fakhfekh, F. \& Zeghal, N., 2014. Nitrate-induced biochemical and histopathological changes in the liver of rats: Ameliorative effect of Hyparrhenia hirta. Biomed. Environ. Sci. 27(9), 695-706. doi.org/10.3967/bes2014.105

Choi, S.Y., Chung, M.J. \& Sung, N., 2002. Volatile N-nitrosamine inhibition after intake of Korean green tea and maesil (Prunus mume sieb. Et zacc.) extracts with an amine-rich diet in subjects ingesting nitrate. Food Chem. Toxicol. 40(7), 949-957. doi.org/10.1016/S0278-6915 (02)00025-X

Elkelawy, H., Mansour, M., El-Naggar, R. and Elkassas, N., 2017. Effect of garlic (Allium sativum) treatment on hematological, biochemical, hormonal and fertility parameters of male Bouscat rabbits. Egyptian Journal of Rabbit Science 27(2),341-357. doi.org/10.21608/EJRS.2017.46587

El-Saber Batiha, G., Magdy Beshbishy, A., G Wasef, L., Elewa, Y.H., A Al-Sagan, A., El-Hack, A., Mohamed, E., Taha, A.E., M Abd-Elhakim, Y. \& Prasad Devkota, H., 2020. Chemical constituents and pharmacological activities of garlic (Allium sativum L.): A review. Nutrients 12(3), 872. doi.org/10.3390/nu12030872

Enovwo, O., 2010. Effects of aqueous extracts of ginger (Zingiber officinale) and onions (Allium cepa) on some biochemical parameters in plasma following oral intake of sodium nitrite by wistar albino rats. M.Sc. thesis, Med. Biochem., Port Harcourt University, Nigeria.

Haskell, S. R., Payne, M., Webb, A., Riviere, J. \& Craigmill, A. L., 2005. Antidotes in food animal practice. Journal of the American Veterinary Medical Association 226(6), 884-887. doi.org/10.2460/javma.2005.226.884

Hassan, H.A., El-Agmy, S.M., Gaur, R.L., Fernando, A., Raj, M.H. \& Ouhtit, A., 2009. In vivo evidence of hepato-and reno-protective effect of garlic oil against sodium nitrite-induced oxidative stress. Int. J. Biol. Sci. 5(3), 249. doi.org/10.7150/ijbs.5.249

Ibrahim, I.A., Hassan, A.G.A., Shalaby, A., Dessouki, A. \& Habib, D., 2009. Biochemical studies on the effect of sodium nitrite and butylated hydroxytoluene in rats. SCVMJ 14(2), 265-278.

Islam, D., Shanta, M.B., Akhter, S., Lyzu, C., Hakim, M., Islam, M.R., Mohanta, L.C., Lipy, E.P. \& Roy, D.C., 2020. Cardioprotective effect of garlic extract in isoproterenol-induced myocardial infarction in a rat model: Assessment of pro-apoptotic caspase-3 gene expression. Clin. Phytosci. 6(1),1-9. doi.org/10.1186/s40816-020-00199-4

Lionel, O.O., Adegboyega, I.P., Ezekiel, A.O. \& Olufunke, B.C., 2020. Antimicrobial activity of garlic (Allium sativum) on selected uropathogens from cases of urinary tract infection. Ann. Trop. Pathol. 11(2), $133-8$. doi.org/10.4103/atp.atp_9_20

Luiking, Y.C., Engelen, M.P. \& Deutz, N.E., 2010. Regulation of nitric oxide production in health and disease. Current opinion in clinical nutrition and metabolic care, 13 (1), 197-104. doi.org/10.1097/MCO.0b013e328332f99d

Lulekal, E., Tesfaye, S., Gebrechristos, S., Dires, K., Zenebe, T., Zegeye, N., Feleke, G., Kassahun, A., Shiferaw, Y. \& Mekonnen, A., 2019. Phytochemical analysis and evaluation of skin irritation, acute and sub-acute toxicity of Cymbopogon citratus essential oil in mice and rabbits. Toxicol. Rep. 6, 1289-1294. doi.org/10.1016/j.toxrep.2019.11.002

Maklad, E., Motawe, H., Ead, H. \& Elshafey, S., 2020. Effect of adding sodium nitrate without or with some feed additives in growing rabbit diets on: 1. Growth performance and economic efficiency. Journal of Animal and Poultry Production 11(9), 367-373. doi.org/10.21608/jappmu.2020.118227

Nakamoto, M., Kunimura, K., Suzuki, J.I. \& Kodera, Y., 2020. Antimicrobial properties of hydrophobic compounds in garlic: Allicin, vinyldithiin, ajoene and diallyl polysulfides. Experimental Therapeutic Med. 19(2), 1550-1553. doi10.3892/etm.2019.8388 
Ogur, R., Coskun, O., Korkmaz, A., Oter, S., Yaren, H. \& Hasde, M., 2005. High nitrate intake impairs liver functions and morphology in rats; protective effects of a-tocopherol. Environ. Toxicol. Pharmacol. 20(1), 161-166. doi.org/10.1016/j.etap.2004.12.051

Ozmen, O. Mor, F. \& Ayhan, U., 2003. Nitrate poisoning in cattle fed Chenopodium album hay. Vet. Hum. Toxicol. 45(2): 83-84.

Pedraza-Chaverri, J., Yam-Canul, P., Chirino, Y.I., Sánchez-González, D.J., Martínez-Martínez, C.M., Cruz, C. \& Medina-Campos, O.N., 2008. Protective effects of garlic powder against potassium dichromate-induced oxidative stress and nephrotoxicity. Food and Chem. Toxicol. 46(2), 619-627. doi.org/10.1016/j.fct.2007.09.088

Qin, L.Z., Jin, L.Y., Qu, X.M. \& Wang, S.L., 2020. Nitrate: A pioneer from the mouth to the systemic health and diseases. Zhonghua kou Qiang yi xue za zhi= Zhonghua Kouqiang Yixue Zazhi= Chinese Journal of Stomatology, 55(7), 433-438. 10.3760/cma.j.cn112144-20200410-00204

Rashid, G., Avais, M., Ahmad, S.S., Mushtaq, M.H., Adil, M., Aqib, A.I., Ali, M., Hasni, M.S., Asif, M., Chang, Y.F. \& Jamal, M.A., 2019. Comparative efficacy of different antidotes against experimental nitrate intoxication in rabbits. J. Exot. Pet. Med. 28(4), 82-89. doi.org/10.1053/j.jepm.2018.02.039

Salama, M.F., Abbas, A., Darweish, M.M., El-Hawwary, A.A. \& Al-Gayyar, M.M., 2013. Hepatoprotective effects of cod liver oil against sodium nitrite toxicity in rats. Pharm. Biol. 51(11), 1435-1443. doi.org/10.3109/13880209.2013.796564

Saracila, M., Panaite, T., Tabuc, C., Soica, C., Untea, A., Ayasan, T. \& Criste, R.D., 2020. Dietary ascorbic acid and chromium supplementation for broilers reared under thermoneutral conditions vs. high heat stress. Lucrări Științifice-Universitatea de Științe Agricole şi Medicină Veterinară, Seria Zootehnie 73,41-47.

Saravanan, G. \& Prakash, J., 2004. Effect of garlic (Allium sativum) on lipid peroxidation in experimental myocardial infarction in rats. J. Ethnopharmacol. 94(1), 155-158. doi.org/10.1016/j.jep.2004.04.029

Sharma, M.K., Sharma, H. \& Bapna, N., 2014. Histopathological changes in kidneys of rabbits exposed to high nitrate ingestion in drinking water. Int. J. Anat. Res. 2,413-417.

Sharma, M.K., Sharma, H. \& Bapna, N., 2013. Histopathological changes in the liver of rabbits exposed to high nitrate ingestion in drinking water. Journal of Clinical and Diagnostic Research 7(8), 1552. doi.org/10.7860/JCDR/2013/6224.3208

Shehata, S., 2010. Nitrate detoxification of drinking water by ascorbic acid in growing rabbits. World Rabbit Sci.13(2), 93106. doi.org/10.4995/wrs.2005.526

Sikandar, A., Cheema, A.H., Younus, M., Aslam, A., Zaman, M.A. \& Rehman, T., 2012. Histopathological and serological studies on paratuberculosis in cattle and buffaloes. Pak. Vet. J. 32(4), 547-551.

Sikandar, A., Zaneb, H., Nasir, A., Adil, M., Ali, H.M., Muhammad, M., Rehman, T., Rehman, A. \& Rehman, H.F., 2020. Effects of Bacillus subtilis on performance, immune system and gut in Salmonella-challenged broilers. S. Afr. J. Anim. Sci. 50(5), 654-662. doi.org/10.4314/sajas.v50i5.2

Singh, R., 2005. Scientific production and management of goats and rabbits. https://www.jainbookagency.com/newdetails.aspx?id=231617

Van Dijk S., Lobsteyn A.J., Wensing T. \& Breukink H.J., 1983. Treatment of nitrate intoxication in a cow. Vet. Rec. 112(12), 272-274. doi: 10.1136/vr.112.12.272.

Waldman, A.D., Fritz, J.M. \& Lenardo, M.J., 2020. A guide to cancer immunotherapy: From T cell basic science to clinical practice. Nat. Immunol. 20, 651-668. doi.org/10.1038/s41577-020-0306-5

Ward, M.H., Kilfoy, B.A., Weyer, P.J., Anderson, K.E., Folsom, A.R. \& Cerhan, J.R., 2010. Nitrate intake and the risk of thyroid cancer and thyroid disease. Epidemiology 21(3), 389-395. doi: 10.1097/EDE.0b013e3181d6201d 